Vol 1, No. 2 (2020), Desember 2020

E-ISSN: 2746-2471, DOI:

\title{
PERCAYA DIRI DAN BERPIKIR STRATEGIS UNTUK MENGHADAPI KETATNYA PERSAINGAN BISNIS
}

\author{
Masayu Endang Apriyanti \\ Fakultas Bahasa dan Seni \\ Universitas Indraprasta PGRI \\ masayuendangapriyanti@gmail.com
}

Dikirim:11 Agustus 2020 Direvisi:29 Desember 2020 Dipublikasikan: 31 Desember 2020

\begin{abstract}
Abstrak
Tujuan penelitian untuk mengetahui pentingnya kepercayaan diri dan kemampuan berpikir strategis dalam menghadapi ketatnya persaingan bisnis, karena masih banyak wirausaha yang kurang percaya diri dan kurang mampu berfikir strategis untuk mempertahankan eksistensi usahanya. Padahal dengan percaya diri yang tinggi dan kemampuan berpikir strategis yang tepat membuat langkahnya tidak goyah, tidak pesimis, gigih berjuang serta berhati-hati demi memenangkan persaingan, sehingga terhindar dari kebangkrutan usaha. Apalagi, saat ini masih ada pandemi COVID-19, yang berdampak banyak hal, salah satunya terhadap sektor ekonomi, yang mempengaruhi permintaan konsumen dan lesunya aktivitas perekonomian. Seharusnya, pengusaha lebih percaya diri dan berpikir strategis, seperti melakukan hal-hal baru, melalui promosi berbeda atau pelayanan lebih baik lagi demi mempertahankan kelangsungan usahanya agar tetap produktif meskipun dimasa sulit. Metode penelitian dilakukan melalui literature dan pengamatan langsung terhadap sampel beberapa pengusaha didaerah Tangerang dan Jakarta Barat. Hasil penelitian membuktikan bahwa dengan percaya diri dan berpikir strategis, pengusaha mampu memenangkan persaingan, terbukti dengan eksistensi mereka dalam menjalankan usaha.
\end{abstract}

Kata kunci : Percaya Diri, Berpikir Strategis, Persaingan Bisnis

\section{A. PENDAHULUAN}

Kondisi saat ini sepanjang ada pandemic COVID-19 benar-benar berdampak pada banyak hal, salah satunya terhadap sektor ekonomi, dimana terjadi penurunan daya beli atau permintaan dari konsumen karena mereka berusaha menghemat pengeluaran dengan bijak, mengatur alokasi keuangan yang dimilikinya dengan sangat selektif, terutama dalam membeli barang atau memakai jasa yang tidak terlalu perlu / tidak mendesak sekali, sehingga suka atau tidak suka banyak perusahaan kecil 


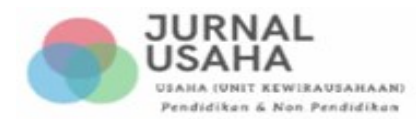

Vol 1, No. 2 (2020), Desember 2020

E-ISSN: 2746-2471, DOI:

maupun besar merasakan dampaknya, dimana kegiatan produksinya menjadi tidak setinggi biasanya, jumlah pendapatan omzet yang menurun, penjualan yang tidak mencapai target seperti sebelum adanya pandemi ini. Jangankan perusahaan yang kecil, perusahaan besarpun ada yang terpaksa bangkrut sebagai akibat karena tidak mampu bertahan dimasa pandemic ini. Karena itulah seharusnya setiap pengusaha memiliki rasa percaya diri yang kuat bahwa usahanya dapat bertahan melalui tahap ujian ini dan harus dapat berfikir strategis untuk menjalankan usahanya agar dapat tetap produktif bagaimanapun caranya, yang penting halal dan baik, misalnya saja dengan menekan biaya produksi yang dapat menurunkan harga jual agar pelanggan tertarik dan mampu membeli produk / jasa yang kita tawarkan, atau juga bisa dengan kegiatan promosi yang unik / berbeda yang mampu menarik kuat pelanggan sehingga mereka dapat setia memakai semua yang kita tawarkan.

Masa pandemi ini memaksa kita harus kuat untuk menghadapi apapun yang terjadi dalam perubahan kehidupan kita, sehingga hidup ini dapat terus berjalan seperti biasanya walaupun pasti ada yang berbeda. Demikian juga bagi para pengusaha, harus siap menghadapi keadaan ini, harus terus Percaya diri akan langkahnya menjalankan usahanya seperti biasa dan mampu berpikir strategis sehingga usahanya dapat terus berjalan walau mungkin tersendat, yang terpenting usaha dapat terus eksis dan produktif hingga dapat terus bertahan. Percaya diri akan sulit dimiliki jika kita minder, karena itu, yakin dan manfaatkan potensi yang ada, jangan pesimis, menyesali diri atau mengeluh,cintai diri kita, lakukan yang bisa dilakukan, jangan menyerah, lihat kesuksesan orang lain, untuk memotivasi kita, jika orang lain bisa sukses, maka kita pun pasti bisa, hanya saja dengan cara yang berbeda, karya berbeda dan tentunya dengan memanfaatkan kelebihan dan kompetensi yang ada pada diri kita masing-masing untuk menciptakan sesuatu yang bermanfaat. Yakinlah bahwa tidak ada satupun manusia yang sempurna, karena kesempurnaan memang hanya milik Tuhan yang maha kuasa, tapi Allah SWT telah membekali kita dengan kelebihan masing-masing agar dapat menghadapi hidup dengan produktif.

Percaya diri sangat penting untuk dimiliki dalam setiap melakukan aktivitas, terutama bagi pengusaha harus percaya diri yang tinggi dalam menjalankan suatu usaha, harus yakin bahwa usahanya ini Insyaallah akan bermanfaat dan meraih sukses, tanpa percaya diri ia tidak mampu mempertahankan kelancaran usahanya, bahkan ia akan pesimis dan menyerah sebelum mencapai kesuksesan yang diharapkannya, karena itu perlu sekali kepercayaan diri agar selalu optimis menghadapi apapun tantangan yang menghadang demi meraih tujuan yang ditargetkan, yang pastinya harus dilakukan dengan kegigihan dan kesungguhan hati untuk tidak bosan terus berjuang meraihnya. Kemampuan berpikir strategis, membantu kita dalam meningkatkan kualitas diri dan karya, melalui berbagai keputusan terbaik yang dipilih, sehingga aktivitas kita berjalan efektif dan efisien dengan hasil optimal. Tidak setiap orang mampu berfikir strategis, terutama bagi 


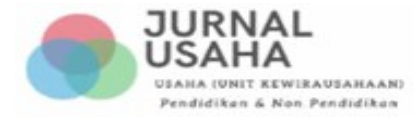

Vol 1, No. 2 (2020), Desember 2020

E-ISSN: 2746-2471, DOI:

pengusaha, harus mampu berfikir strategis dalam menjalankan usaha, agar dapat mempersiapkan langkah - langkah terbaik, orang-orang terbaik dan setia, dapat mengalokasikan seluruh sumber daya dengan tepat, bersikap terbaik dalam menghadapi segala situasi, yang akhirnya dapat menghasilkan laba, mencapai target dan kesuksesan. Persaingan sebenarnya tidak hanya ada dalam bisnis saja, persaingan selalu saja ada sepanjang hidup kita, bahkan jika mengenang masa lalu, kita sudah kerap kali bersaing di masa-masa sekolah untuk mendapatkan nilai terbaik atau rangking terbaik dikelas, bersaing mendapatkan juara pada suatu perlombaan, bersaing mendapatkan semua yang kita inginkan, bersaing mendapatkan pekerjaan impian yang diidam-idamkan sejak lama, atau bahkan kita juga bersaing untuk mendapatkan pujaan hati yang akan bersanding menemani kita sepanjang hidup ini, karena persaingan tersebut sudah biasa kita hadapi dan kita mampu melaluinya sampai saat ini, maka sebaiknya ketika kita menjadi seorang pengusaha, kita harus siap, kuat dan sangat gigih untuk memenangkan persaingan bisnis ini, demi kelangsungan masa depan usaha yang kita jalankan dan demi kesejahteraan para pegawai dan pihak yang terlibat dalam usaha kita.

Dimasa pandemi COVID-19 ini, daya beli masyarakat turun, ekonomi terasa semakin sulit, ada kebijakan yang membatasi ruang gerak dalam operasional usaha dan ketentuan-ketentuan lainnya, membuat persaingan bisnis semakin ketat untuk menarik daya beli konsumen terhadap produk/jasa yang kita tawarkan, apalagi konsumen saat ini akan lebih selektif lagi dalam menggunakan uangnya dalam arti hanya menggunakan uang untuk keperluan mendesak saja, artinya para pengusaha harus benar-benar berfikir strategis untuk menghadapi keadaan saat ini, dengan berbagai macam kebijakan terbaik yang seharusnya di putuskan, misalkan saja dengan melalui strategi cara-cara promosi atau pelayanan ekstra untuk konsumen. Untuk memenangkan persaingan bisnis yang ketat ini, para pengusaha dituntut untuk kreatif dan inovatif menghadapinya, dan semua itu haruslah dimulai dengan berfikir strategis, setelah proses berfikir dilalui, barulah dapat dilaksanakan / diwujudkan konsep apa saja yang ada didalam pikirannya kedalam bentuk tindakan / keputusan nyata, yang kemudian akan dapat di implementasikan dalam usahanya, karena jika perusahaan menang dalam persaingan usaha, maka ia dapat mempertahankan eksistensi dan kontinuitas usaha yang dijalankannya. Jangan takut menghadapi apapun, yakinlah kita memiliki kemampuan untuk berkarya, terus berusaha dan bekerja keras semaksimal mungkin dan yang terpenting jangan putus asa untuk lakukan yang terbaik dan terus berdoa pada yang maha kaya, Insyaallah usaha yang kita lakukan akan sukses. Implementasi dari hasil berfikir strategis tersebut nanti dapat berupa kebijakan, model operasional, aturan alokasi sumber daya yang ada, pemilihan bahan-bahan terbaik untuk produksi, cara promosi atau bentuk pelayanan ekstra untuk konsumen, perubahan alur pelaksanaan operasional dan sebagainya untuk memenangkan persaingan bisnis yang semakin ketat. 
Vol 1, No. 2 (2020), Desember 2020

E-ISSN: 2746-2471, DOI:

\section{B. KAJIAN PUSTAKA}

Allah SWT berfirman dalam Al-Qur'an, "Janganlah kamu bersikap lemah, dan janganlah (pula) kamu bersedih hati, padahal kamulah orang-orang yang paling tinggi (derajatnya), jika kamu orang-orang yang beriman". (Q.S Ali Imran: 139). Makna dari firman Allah dalam ayat ini adalah kita sebagai manusia diperintahkan untuk menjadi sosok yang kuat, tegar, jangan cengeng menghadapi kerasnya hidup ini, jangan mudah putus asa jika ada masalah yang menghadang, karena manusia adalah sebaik-baik ciptaanNya, dan kita dapat menjadi orang-orang yang baik dihadapanNya jika kita dapat menjadi manusia yang bermanfaat untuk banyak orang, kita dapat memanfaatkan semua yang Allah berikan pada kita, baik yang berupa ilmu pengetahuan, potensi diri, kelebihan / bakat / kemampuan yang dimiliki, wawasan yang ada atau bisa juga pengalaman hidup yang sudah dilalui, itu semua dapat dimanfaatkan agar kita menjadi sosok yang lebih baik dan berkualitas lagi dibanding hari kemarin. Sesungguhnya Allah memerintahkan kepada kita semua agar kita percaya diri dan tidak putus asa dalam mencari rahmat dan hidayah Allah SWT. Kita sebagai manusia wajib ikhtiar kepada Allah SWT karena semua masalah pasti ada jalan keluarnya.(Mamlu'ah 2019). Selama kita tidak berputus asa dan menyerah maka solusi pasti ada, yang penting jangan pernah berhenti berusaha untuk melakukan yang terbaik di setiap kesempatan yang ada.

Kepercayaan diri merupakan suatu keyakinan dalam jiwa seseorang bahwa tantangan hidup apapun harus dihadapi dengan berbuat sesuatu. kepercayaan diri merupakan sikap atau perasaan yakin yang dimiliki seseorang terhadap kemampuan diri sendiri, sehingga tidak akan terpengaruh dengan orang lain.(Rifati et al. 2018). Dengan percaya diri yang dimiliki seseorang tidak akan mudah dipengaruhi, tidak mudah dipatahkan atau dijatuhkan oleh orang lain, karena ia focus dalam menjalankan sesuatu, tidak ada waktu yang terbuang sia-sia sehingga tidak mudah goyah hanya karena hasutan atau pengaruh dari orang lain. Optimism : Optimis adalah sikap positif yang harus dimiliki oleh para wirausahawan, mereka yang menanamkan sikap ini seakan-akan mempunyai gambaran keberhasilan yang akan diperolehnya. (Argene, 2003 : 5). Sikap optimis ini tidak akan bisa muncul tanpa adanya rasa percaya pada diri kita bahwa kita mampu melakukannya. A man who knows himself can step outside himself and watch his own reactions like an observer - Adam Smith. (Rachman, 2016 : 335), bermakna bahwa dengan percaya diri maka kita siap menghadapi tantangan yang menghadang, kita bersemangat penuh meraih tujuan, kita berani ambil resiko atas setiap keputusan langkah yang diambil, mampu memanajemen konflik yang mungkin saja dapat terjadi dalam sebuah hubungan dan dapat memilih serta membina mitra terbaik dalam menjalankan setiap aktivitas untuk mendukung pencapaian sebuah tujuan / kesuksesan.

Dengan percaya diri kita akan yakin dapat melakukan dan memberikan yang terbaik dalam hidup ini dengan serius fokus untuk memanfaatkan segala potensi dan 


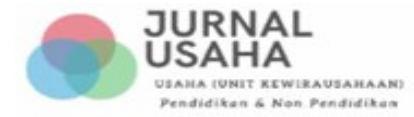

Vol 1, No. 2 (2020), Desember 2020

E-ISSN: 2746-2471, DOI:

kelebihan yang ada pada diri kita untuk mencapai sebuah kesuksesan dan pencapaian tujuan hidup yang diharapkan. Seperti dalam bukunya Eileen Rachman yang berkata bahwa Keyakinanlah yang memberi kekuatan untuk mengambil resiko, bertindak dan membuat keputusan (Rachman, 2016 : 153). Seharusnya dalam melakukan sesuatu yang berawal dari pikiran dan niat janganlah dikontaminasi dengan prasangka negatif, bersikaplah positif akan segala hal, dan andaipun jika terjadi sesuatu hal yang negatif terhadap diri kita yang tidak sesuai dengan yang diharapkan, usahakanlah hadirkan dalam pikiran kita tentang beratus alasan positif sehingga waktu dan pikiran kita tidak terpenjara pada perasaan / penilaian negatif terhadap suatu hal tersebut, karena selama kita berfikir dan bertindak positif, sesungguhnya kita tenang menjalani hidup ini, kita bahagia dan merasa sukses dalam melalui setiap rintangan yang menghadang, seperti dalam buku Eileen ranchman yang berkata, begitu kita memulai sesuatu dengan sikap negatif, kita tidak mempunyai kesempatan untuk memulai sesuatu yang baik. ( Rachman, 2016 : 423). Berpikir strategis adalah menciptakan kaitan antara ide, rencana dan individu-individu yang tidak selamanya terlihat oleh orang lain. (Rachman, 2016 : 87). Berpikir strategis berarti kita mampu memilih cara,keputusan terbaik yang harus diambil, mampu memikirkan banyak hal, mempertimbangkan dengan matang setiap keputusan untuk tindakan tertentu, siap terhadap konsekuensi tas tindakannya.

Berpikir strategis merupakan awal untuk memutuskan suatu tindakan tertentu, seperti berpikir strategis untuk bertindak memutasi seseorang demi peningkatan kualitas kerja dirinya, kualitas kerja tim, sampai pada peningkatan kualitas perusahaan, atau tindakan strategis kita dalam membina hubungan hangat dan bersahabat pada mitra demi kepentingan masa depan, jadi berpikir strategis bukan langkah akhir, melainkan awal dari melakukan suatu tindakan terbaik untuk menjaga stabilitas perusahaan dalam mencapai tujuannya. Kekuatan sebuah Negara bukan hanya terletak pada ketahanan nasional, kekayaan alam, atau bahkan kemajuan tekhnologi, namun yang terutama justru pada manusia-manusia yang ada didalamnya. (Rachman, 2016 : 101). Kita perlu berambisi untuk senantiasa memperkuat kompetensi kerja kita (Rachman, $2016: 41$ ). Dari kalimat tersebut, hendaknya kita termotivasi untuk memanfaatkan kemampuan berpikir kita sebaik-baiknya, ambisi disini artinya optimis melakukan kegiatan tertentu, terus berusaha pantang menyerah melakukan segala yang terbaik, mengasah kemampuan, kompetensi diri dan hasil kerja, lalu didukung oleh percaya diri yang kuat akan kemampuan yang dimiliki, maka kita akan dapat menjalankan aktivitas apapun dengan fokus sehingga mampu mencapai tujuan dengan optimal. Bisnis adalah aktivitas yang dilakukan oleh seseorang atau sekelompok orang atau perusahaan dalam bentuk jasa atau barang untuk memperoleh laba. (Soegoto, 2014 : 40). Maka, agar eksis dalam bisnis, maka perusahaan harus mampu menghadapi persaingan dengan strategi terbaiknya, sehingga ia mampu mempertahankan kelangsungan hidup usaha, membayar gaji karyawan dengan nilai sepadan, suasana kerja kondusif yang mendorong karyawan agar terus bekerja dengan baik, tata kerja terstruktur dan etika bisnis yang dijunjung 


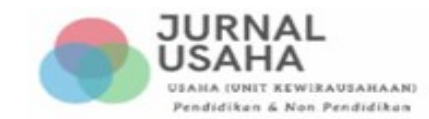

Vol 1, No. 2 (2020), Desember 2020

E-ISSN: 2746-2471, DOI:

tinggi, serta didukung oleh sarana prasarana yang tersedia, serta dapat melayani konsumen dengan optimal.

Persaingan bisnis selain terjadi karena adanya seseorang yang menjalankan bisnis di bidang yang sama dengan lainnya juga dapat disebabkan karena beberapa hal. Seperti, ketidak mampuan pelaku bisnis sebelumnya untuk menciptakan produk atau jasa yang lebih memenuhi kebutuhan konsumen.(Zahiraccounting 2020). Dan persaingan bisnis ini merupakan resiko yang harus dihadapi setiap dunia usaha. Setiap pengusaha memiliki strategi berbeda-beda dalam menjalankan operasional perusahaannya, yang semuanya adalah untuk mencapai tujuan kesuksesan / tujuan yang ditargetkan, dan salah satunya adalah dengan memiliki rasa percaya diri yang kuat dan terus berpikir strategis untuk menghadapi persaingan bisnis sepanjang masa. Seperti ungkapan dari Eileen Rachman bahwa Berpikir memang perlu, tetapi kita perlu melakukan sesuatu dan tak perlu menunggu sampai hasil pemikiran kita benarbenar sempurna. Lakukan sesuatu, dengarkan intuisi anda, dan bergeraklah sesuai kata hati. (Eileen Rachman, 2016 : 13). Hal yang diperlukan untuk kelancaran usaha, adalah : 1. Memuaskan pelanggan 2. Pertumbuhan (growth), 3. Penekanan biaya 4).Inovasi dan fiture terbaru dari sebuah merk 5. Mengamati kejadian dengan cepat untuk mengambil tindakan-tindakan yang efektif 6 . Kualitas dari barang yang akan di produksinya. ( Robert Argene, 2003 : 31) ini sebagai salah satu contoh dari beberapa alternatif bertindak yang berawal dari proses berpikir strategis terkait operasional perusahaan agar seluruh kegiatan lancar.

Pesatnya perkembangan kemajuan teknologi mempengaruhi penyampaian informasi secara cepat dan mudah diketahui seluruh dunia, seperti informasi mengenai keadaan pasar, minat konsumen, harga bahan mentah, juga membuka kesempatan luas bagi perusahaan untuk membuka cabangnya di dalam maupun luar negeri, karena proses jalinan komunikasi sangat mudah dan cepat, tidak seperti dahulu ketika kemajuan teknologi belum semaju ini. Karena itu, sebaiknya pengusaha mampu berpikir strategis dengan memanfaatkan kemajuan teknologi untuk perkembangan usahanya, sehingga melalui integrasi informasi akurat, tepat dan harmonis, dapat menghasilkan kinerja lebih efektif dan efisien serta produktivitas tinggi.

\section{METODE PENELITIAN}

Penelitian ini menggunakan pendekatan kualitatif dengan metode deskritif yang bersifat mempelajari kejadian dilapangan yang memungkinkan untuk melakukan hubungan antar variabel, menguji hipotesis, mengembangkan generalisasi, dan mengembangkan teori yang memiliki validitas universal. Metode deskriptif adalah suatu metode dalam meneliti status sekelompok manusia, objek, kondisi, sistem pemikiran ataupun suatu kelas peristiwa pada masa sekarang. Tujuan dari penelitian deskritif ini adalah untuk membuat deskripsi, gambaran atau lukisan secara 
Vol 1, No. 2 (2020), Desember 2020

E-ISSN: 2746-2471, DOI:

sistematis, faktual dan akurat mengenai fakta, sifat serta hubungan antar fenomena yang diselidiki ( Sugiyono, 2007 : 11 ). Beberapa fenomena yang dilihat hubungannya adalah rasa percaya diri yang tinggi dan kemampuan berpikir strategis dan keberhasilan pengusaha dalam menghadapi ketatnya persaingan bisnis. Metode pengumpulan data dalam penelitian ini adalah literature dan observasi langsung. Penelitian berlangsung bulan September dan oktober 2020.

\section{HASIL DAN PEMBAHASAN}

Persaingan dunia usaha yang semakin ketat, dengan dinamika kehidupan yang semakin beragam dan persaingan mendapat kehidupan layak yang semakin menantang, seharusnya mendorong kita untuk melakukan yang terbaik dari sumber daya yang kita miliki atau yang ada di sekitar kita.(Apriyanti 2020). Persaingan dalam bentuk apapun pasti ada dan harus dihadapi, jika mampu memenangkannya, kita dapat bertahan, jika tidak, maka kita akan kalah dan tergusur dari komunitas usaha tersebut. Terbentuknya konsep percaya diri, terbentuknya kepribadian yang baik sesuai dengan proses perkembangan yang melahirkan kelebihan-kelebihan tertentu. yaitu 1.Pemahaman seseorang terhadap kelebihan-kelebihan yang dimilikinya dan melahirkan keyakinan yang kuat untuk bisa berbuat segala sesuatu dengan memanfaatkan kelebihan-kelebihannya.2.Pemahaman dan reaksi positif seseorang terhadap kelemahan-kelemahan yang dimilikinya agar tidak menimbulkan rasa rendah diri atau sulit menyesuaikan diri.3.Pengalaman didalam menjalani berbagai aspek kehidupan dengan menggunakan segala kelebihan yang ada pada diri sendiri.(Mamlu'ah 2019).Berarti dengan percaya diri yang tinggi, maka kita semua mampu memanfaatkan kelebihan yang ada pada diri kita untuk hal positif dan menghasilkan sesuatu yang bermanfaat. Demikian juga hal nya pengusaha, terlebih untuk pengusaha pemula yang baru saja bergabung kedalam dunia bisnis, maka tidak perlu risau, gelisah atau takut, yakinlah bahwa kita dapat memberikan yang terbaik dan bermanfaat untuk banyak orang dengan karya yang kita hasilkan yang penting adalah tidak sombong, ma uterus belajar dan tidak lelah untuk terus berusaha memperbaiki dan meningkatkan lagi kualitas diri kita.

Innovation is the specific instrument of entrepreneurship, the act that endows resources with a new capacity to create wealth - Prof. Dr. Peter F. Drucker (Diandra, 2016 : 54). Inovasi adalah instrument khusus kewirausahaan, tindakan yang memberi sumber daya suatu kemampuan baru untuk menciptakan kekayaan, maknanya inovasi meningkatkan kinerja perusahaan, karena prinsipnya menciptakan produk/jasa terbaik untuk pelanggan, sehingga setiap elemen perusahaan terdorong memanfaatkan berbagai sumberdaya yang ada untuk menambah nilai lebih untuk produk/jasa yang diciptakan, seperti berfikir strategis yang menelurkan ide cemerlang, lalu diwujudkan dengan dukungan pemanfaatan sentuhan kemajuan teknologi saat ini yang sudah berkembang sangat pesat. 
Vol 1, No. 2 (2020), Desember 2020

E-ISSN: 2746-2471, DOI:

Strategi penggunaan tekhnologi informasi dan komunikasi bisnis menuju keunggulan kompetitif : 1. Strategi biaya (menjadi produsen dengan biaya rendah, memberi harga lebih murah pada pelanggan, menurunkan biaya dari pemasok, atau meningkatkan biaya pesaing untuk tetap bertahan industry) 2. Strategi diferensiasi (mengembangkan cara membedakan produk/jasa yang dihasilkan perusahaan terhadap pesaing, sehingga pelanggan menggunakan produk/jasa karena adanya manfaat atau fitur yang unik) 3. Strategi inovasi (memperkenalkan produk/jasa yang unik, perubahan radikal dalam proses bisnis yang menyebabkan perubahan mendasar dalam pengelolaan bisnis), 4. Strategi pertumbuhan (meningkatkan kapasitas produksi secara signifikan, ekspansi ke pemasaran global, diversifikasi produk/jasa baru, atau mengintegrasikan kedalam produk/jasa terkait) 5. Strategi Aliansi (membentuk hubungan dan aliansi bisnis baru dengan pelanggan, pemasok, pesaing dan lainnya) (Feriyanto dan Triana, 2015:48). Sebagai pengusaha yang ingin sukses, maka salah satunya dapat melalui kemampuan dalam menggunakan kemajuan teknologi untuk menunjang pertumbuhan dan perkembangan usaha, jangan sampai tertinggal oleh pesatnya kemajuan teknologi saat ini, karena jika tertinggal atau tidak dapat mengimbangi dan memanfaatkannya dengan baik, maka usaha yang dijalankan sangat mungkin dapat berakhir atau pailit, karena tidak mempu bertahan.

Temukan saja satu hal yang paling kuat dalam diri anda, dan fokuslah disitu (Diandra, 2016, 21) Fokus pada kekuatan diri, manfaatkan untuk berkarya dalam menghadapi persingan yang ada, selama ada kemauan, ada tekad dan keyakinan serta usaha sungguh-sungguh, Insya Allah pasti ada jalan meraih harapan, dan pilihlah jalan yang paling mendekati kita, misalnya kita memiliki kemampuan terkait dunia desain komunikasi visual, maka jalankan usaha yang berkecimpung tentang DKV, agar kesuksesan lebih mudah didapatkan.Berfikir strategis dalam memberikan pelayanan exelent kepada pelanggan juga harus dipersiapkan dengan baik, karena setiap pelanggan selalu ingin mendapatkan service terbaik dari setiap harga yang dibayarnya, atau dengan kata lain pelanggan rela membayar berapapun selama ia mendapatkan pelayanan terbaik, berarti setelah dipikirkan bagaimana strategi terbaik, maka segera gunakan peluang ini untuk melakukan tindakan paling tepat demi kepuasan pelanggan yang akan mengikat kesetiaan mereka terhadap perusahaan kita.

Kiat pelayanan prima adalah P : Professional, R : Ramah, I : Ikhlas, M : Mutu, A : Antusias. (Feriyanto dan Triana, 2015 : 183), setiap pengusaha pasti melakukan berbagai usaha untuk memenangkan persaingan, maka, menurut hemat saya, makna dari kalimat pelayanan prima tersebut berarti kita memberikan kepuasan maksimal untuk pelanggan, karena dengan sikap profesional, pelanggan akan dilayani sesuai standard operasional prosedur yang ditetapkan, dilayani secara hangat dengan keramahan setiap karyawan, sehingga merasakan kesan ketulusan dari pelayanan yang didapat. Lalu menimbulkan keterikatan batin yang kuat antara perusahaan dan pelanggan, mutu / kualitas terjaga akan membuat pelanggan puas membeli produk/jasa kita, dan antusias perusahaan memberikan terbaik untuk pelanggan, pasti 


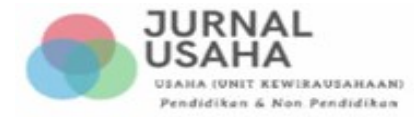

Vol 1, No. 2 (2020), Desember 2020

E-ISSN: 2746-2471, DOI:

mendorong pelanggan antusias terhadap setiap produk/jasa kita, selama pelanggan puas dan setia pada perusahaan, hal tersebut mendukung perusahaan memenangkan persaingan bisnis. Kita memang sering mengambil keputusan atau melakukan tindakan yang tidak masuk akal (nonsense). Dan seperti kata Feynman, we are the easiest person to fool. Oleh karenanya, apapun yang hendak kita kerjakan sangat penting menyadari keterbatasan kita tersebut, bahwa kita sering bertindak bodoh, kita sering melakukan hal yang tidak make sense, yang penting, bagaimana kita mengurangi dan membatasi kelemahan tersebut. (Iman, 2017 : 30). Agar jangan sampai salah langkah dan melakukan kebodohan yang sama, maka diperlukan kemampuan berpikir strategis sebelum bertindak agar dapat mempersiapkan strategi terbaik dengan diimbangi kekuatan dan kelemahan yang ada dan meminimalisir kemungkinan resiko terburuknya.

Dengan berpikir strategis sesungguhnya kita memulai dari perencanaan untuk melakukan sesuatu tindakan yang strategis dalam menjalankan suatu usaha, setelah perencanaan lalu kita akan menentukan keputusan dan tindakan langkah yang harus diambil untuk meraih tujuan yang ingin dicapai, karena itu sebaiknya ketika berfikir strategis, harus dipikirkan semua aspek dari berbagai sudut pandang sehingga keputusan yang diambil adalah baik untuk semua pihak yang terkait. Perencanaan strategis adalah proses memformulasikan, mengimplementasikan dan mengevaluasi keputusan yang memungkinkan organisasi mencapai tujuannya. (Wibowo, $2017: 37$ ), artinya, melalui perencanaan strategis yang matang maka kita dapat melaksanakan strategi terbaik meraih tujuan.

Langkah untuk meningkatkan rasa percaya diri, 1. Kemas diri anda selayaknya menjadi orang sukses, 2. Perbaiki postur tubuh anda 3. Lakukan yang terbaik dan kurangi rasa khawatir 4. Focus pada masa depan 5. Jadilah postif 6. Lepaskan kesalahan kecil 7. Lanjutkan untuk tumbuh dan berkembang 8. Jadwalkan waktu untuk bermain / hobi dengan keluarga 9. Jangan takut untuk meminta nasihat. Pemimpin yang baik harus yakin pada diri sendiri, dan bisa menjadi teladan bagi anggotanya. Dengan meningkatkan percaya diri, Anda akan lebih yakin untuk mengambil keputusan dalam bisnis. Lakukan hal-hal di atas untuk menjadi pribadi yang lebih hebat dari sebelumnya. (Fathya 2014). Manfaat memiliki kepercayaan diri yang kuat adalah 1. Lebih bersemangat menjalankan setiap aktivitas 2. Tidak Takut Menghadapi Kegagalan, karena persiapan matang dan antisipasi hal yang mungkin terjadi, 3. Memiliki kesehatan lebih baik dan kuat, tidak minder, tidak iri dan fokus berkarya sesuai kemampuan yang ada 4 . Memperlancar setiap aktivitasnya baik dalam Berkarier maupun dalam berwirausaha 5. Mampu menciptakan Peluang 6. Berani menjadi diri sendiri dengan jati diri yang kuat 7. Cinta pada diri sendiri dan bahagia 8. Optimis menjalani hidup 9. Lebih mudah meraih kesuksesan karena keyakinan hati dalam melakukan sesuatu 10. Berusaha terus untuk mengembangkan kemampuan 11. Mampu mengekspresikan diri dengan positif dan menghasilkan beragam manfaat 2 . Berusaha menggapai impian dan harapan secara realistis dengan 
Vol 1, No. 2 (2020), Desember 2020

E-ISSN: 2746-2471, DOI:

kemampuan dan kesempatan yang dimiliki 13. Mampu memanajemen diri dengan baik dan siap dipimpin dengan baik juga 14. Siap dikritik, di cemooh, dihina, dijatuhkan, diremehkan, bahkan di fitnah sekalipun, namun didalam diri tetap ada keyakinan dan rasa percaya diri untuk selalu berada dijalan yang benar, kritik pedas menjadi cambuk bagi diri untuk menjadi pribadi lebih berkualitas 16. Memiliki Mentalitas yang kuat, tahan banting terhadap apapun.

Kunci sukses memulai bisnis yakni jeli melihat peluang bisnis, memiliki ide cemerlang, tekad diri yang kuat, dan modal diri $7 \mathrm{~K}$ : kompetensi, kecerdasan, keberanian, keyakinan, ketekunan, keuletan, kerajinan. (Soegoto, 2014 : 95). Kunci sukses tersebut dapat diwujudkan, salah satunya dengan berfikir strategis, karena cara berfikir seseorang dan bentuk ide yang dimiliki pasti berbeda-beda, yang tentunya sangat dipengaruhi oleh karakter masing-masing, pengalaman hidup maupun keahlian yang ada pada diri. Strategi adalah serangkaian keputusan dan tindakan mendasar yang dibuat oleh manajemen puncak dan di implementasikan oleh seluruh jajaran suatu organisasi dalam rangka pencapaian tujuan organisasi tersebut menurut Siagian (dalam Muhyi, Muttaqin dan Nirmalasari, 2016 : 24), Hal tersebut dapat dimaknai, bahwa berpikir strategis merupakan langkah awal usaha mendapatkan ide-ide bagus dalam melancarkan dan meningkatkan kemajuan bisnisnya, misalnya berfikir strategis terkait hal mengatur strategi pemasaran, mulai dari perencanaan, penentuan segmentasi, pemilihan marketing mix-nya, strategi bauran pemasarannya atau perluasan pemasaran akan produknya, bagaimana melakukan perlindungan pasarnya, mempertahankan pelanggan, sampai bagaimana mencari atau menambah pelanggan baru. Berfikir strategis yang dilakukan perusahaan atau pihak manajemen pucak meliputi banyak hal untuk mencapai kesuksesan yang diinginkannya, antara lain mereka dapat berfikir dan menyiapkan strategi tentang pengelolaan, pengalokasian dan pemanfaatan sumber daya manusia secara efektif untuk mendukung performa bisnisnya, bisa berfikir tentang strategi dalam mengatur operasional perusahaan dan peningkatan produktivitas kinerja masing-masing, strategi pemasaran agar setiap output yang dihasilkan dapat didistribusikan dengan baik dan tidak menumpuk digudang, bisa juga strategi dalam membina hubungan baik dengan pelanggan dan seluruh relasi yang ada, dan lain sebagainya.

Berfikir strategis jika dibahas semuanya sangat luas sekali, penulis disini lebih mengarahkan penulisan dan penelitian pada spesifikasi dalam hal kemampuan menghadapi ketatnya persaingan usaha, berarti perusahaan / pengusaha harus mampu berfikir strategis dan menyiapkan strategi terbaiknya dalam memenangkan persaingan yang ada, antara lain dalam mendapatkan dan mempertahankan pelanggan yang ada, karena pelanggan merupakan unsur kuat yang membuat suatu perusahaan sanggup bertahan dan melanjutkan kelangsungan hidup usahanya, karena tanpa pelanggan perusahaan akan mati. Membangun sistem pemasaran secara holistik melalui integrated marketing, relationship marketing, internal marketing, dan social responsibility marketing dengan strategi pemasaran yang tepat akan meningkatkan 


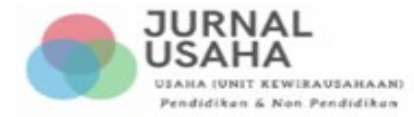

Vol 1, No. 2 (2020), Desember 2020

E-ISSN: 2746-2471, DOI:

keunggulan bersaing perusahaan. (Soegoto, $2014: 161$ ). Berarti perusahaan harus berfikir bagaimana strategi pemasaran terbaik yang harus dilakukannya mulai dari proses perencanaan, tahap pelaksanaannya sampai pada terciptanya kepuasan kebutuhan pelanggan dan perusahaan, agar proses pemasaran berjalan lancar tanpa kendala, dan produk/jasa pun sampai ketangan konsumen dengan baik serta konsumenpun puas atas apa yang dia dapatkan dari setiap harga yang dibayarkan.

Strategi pemasaran adalah perencanaan, implementasi, dan pengendalian komunikasi dari suatu organisasi kepada para konsumen serta sasaran lainnya. (Soegoto, 2014 : 293). Salah satu usaha untuk mendapatkan dan mempertahankan pelanggan dalam strategi pemasaran, maka kita dapat melakukan strategi promosi yang tepat, dimana pelaksanan promosi tersebut tidak harus selalu dengan biaya mahal, dengan iklan yang mewah, atau pemeran iklan harus dari artis ternama, karena yang terpenting adalah promosi tersebut harus tepat penyajiannya dan tepat sasaran. Strategi pemasaran merupakan sebuah upaya memasarkan suatu produk, baik itu barang atau jasa, dengan menggunakan pola rencana dan taktik tertentu sehingga jumlah penjualan menjadi lebih tinggi. Dapat diartikan strategi pemasaran yaitu suatu cara yang dilakukan oleh perusahaan dalam rangka mencapai tujuan tertentu, karena potensi untuk menjual produk terbatas pada jumlah orang yang mengetahui hal tersebut.(Hosting 2019). Promosi wajib dilakukan oleh setiap perusahaan, baik yang baru berdiri maupun yang sudah lama. (Soegoto, $2014: 292$ ). Artinya promosi harus dilaksanakan terus agar konsumen mengenal dan mengingat produk/jasa yang kita tawarkan, melalui promosi kita berkesempatan meraih pelanggan baru atau membuka pasar menjadi lebih luas dan sekaligus dapat terus terhubung dengan konsumen kita.

Strategi untuk Promosi pemasaran atas produk, dapat kita dilakukan dengan 1. Memanfaatkan media sosial baik yang gratis maupun yang berbayar 2. Mensponsori suatu acara 3. Membagikan produk kita pada suatu acara atau tempat tertentu, contoh sumbangan paket produk kita untuk anak panti asuhan sebagai santunan untuk mereka, atau sebagai paket hadiah yang menghadiahi pemenang-pemenang suatu perlombaan tertentu. 3. Memberi insentif pada pelanggan yang memberikan rekomendasinya akan produk/jasa kita, contohnya seperti yang dilakukan oleh indovision, setiap pelanggan yang mengajak/merekomendasikan kepada orang lain untuk berlangganan indovision, maka diberikan gratis akan biaya bulanan selama 3 bulan, dan sebagainya. 4. Pergunakan barang promosi, misalnya, kita memberikan hadiah kalender, mug, kaos, tas yang tercetak logo brand perusahaan kita, kepada pelanggan setia kita, dan ketika mereka memakainya, maka orang lain yang melihat dapat tertarik akan produk kita. Dan empat strategi promosi pemasaran ini adalah salah satu cara yang dilakukan untuk memenangkan persaingan bisnis dalam rangka mendapatkan dan mempertahankan pelanggan agar usaha kita sukses bahkan terus berkembang dan maju lagi.

Manfaat persaingan bisnis adalah 1. Menghadirkan motivasi tinggi bagi pelaku bisnis untuk terus berkarya dengan kualitas terbaik dan semakin baik lagi, 2 . 


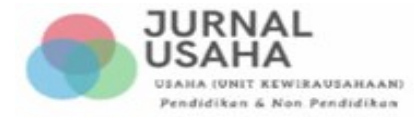

Vol 1, No. 2 (2020), Desember 2020

E-ISSN: 2746-2471, DOI:

Meningkatkan kinerja bisnis, melalui peningkatan input yang ada didalam perusahaan, bisa dari peningkatan kemampuan dan keahlian masing-masing personil didalam perusahaan, peningkatan perlengkapan / peralatan yang disediakan perusahaan dan faktor input pendukung lainnya 3. Menciptakan pelanggan yang loyal dimana dengan adanya persaingan bisnis ini, maka selayaknya setiap perusahaan mampu berfikir strategis dalam menentukan kebijakan dan langkah yang akan dilakukannya demi mencapai tujuan kesuksesan yang diharapkan bersama dan memberikan segala yang terbaik bagi konsumen dan bagi stakeholders didalam perusahaan.

Cara memenangkan persaingan bisnis antara lain, dengan konsep bisnis yang jelas, tempat lokasi usaha yang tepat, menganalisa persaingan, menyusun tim kerja yang efektif dan tepat, berpromosi dan beriklan, pelayanan yang memuaskan bagi pelanggan, jalin hubungan yang baik dengan pelanggan, perhatikan kualitas produk, evaluasi dan inovasi, fokus memperkuat brand / merk perusahaan.(Izna Faruq 2020). Jika kita ingin menang dalam persaingan maka harus dimulai dari 1. konsep bisnis yang dijalankan, dimana visi misinya harus jelas dan pasti, tidak ikut-ikutan orang lain, tidak mudah terpengaruh atau dipengaruhi oleh orang lain, jika kita mempunyai prinsip dan konsep yang jelas dalam menjalankan usaha apapun. 2. Tempat lokasi tepat disini bisa diartikan lokasi yang strategis dengan usaha yang dilakukan, salah satu contohnya membuka usaha restoran mewah maka carilah lokasi yang dekat dengan perumahan elit, apartemen kelas atas, dekat dengan lokasi pariwisata ternama, karena jika ia membuka restoran mewah namun lokasi usahanya di sekitar perumahan menengah, usahanya tidak dapat berjalan lama, karena harga produk yang ditawarkan oleh restoran mewahnya tersebut tidak dapat dijangkau oleh pasar yang ada disekitarnya, atau andaipun ada yang bisa menjangkau harganya, mungkin hanya sesekali saja dan tidak dapat menjamin kontinuitas perusahaan, maka harus dipikirkan tentang lokasi tempat usaha karena sangat berpengaruh dengan biaya operasional, keuntungan dan kekuatan berdirinya suatu perusahaan. 3. Menganalisa persaingan disini berarti kita harus dapat melakukan SWOT atas usaha dan pesaing yang ada disekitar usaha yang kita jalankan, agar dapat mengantisipasi kemungkinan yang tidak kita inginkan, dapat meminimalisir resiko yang ada dan yang terutama dapat focus memanfaatkan kelebihan dan kekuatan yang ada pada diri kita dalam berkarya. 4. Menyusun tim kerja secara efektif dan efisien, berarti kita memilih dan menetapkan orang-orang yang tepat sesuai dengan kualifikasi yang dibutuhkan pada masing-masing posisi, didalam prinsip manajemen sumber daya manusia adalah melaksanakan the right man on the right place, agar kinerja setiap personil, kinerja tim dan kinerja perusahaan dapat tercipta secara baik 5. Berpromosi dan beriklan, kita harus dapat menyesuaikan dengan budget yang ada, jangan memaksakan diri berpromosi/beriklan yang mahal jika tidak memiliki budget yang cukup, lakukan promosi sesuai kemampuan saja yang penting tepat sasaran dan tepat waktu penyampaiannya sehingga dapat berjalan efektif dan efisien. 6. Pelayanan yang memuaskan bagi pelanggan disini artinya kita selalu memprioritaskan kepuasan 
Vol 1, No. 2 (2020), Desember 2020

E-ISSN: 2746-2471, DOI:

pelanggan, jangan pernah mengecewakannya, berikanlah servis terbaik disetiap kesempatan 7. Jalin hubungan baik dengan pelanggan itu dapat dimaksudkan bahwa sepanjang kita melayani pelanggan, kita melakukannya sepenuh hati, ikhlas, ramah, dan bersahabat, sehingga memberikan kesan terbaik dan menyenangkan, maka hal tersebut dapat mengikat hati pelanggan sehingga mereka selalu ingin dan suka berhubungan dengan kita dan dampaknya adalah mereka akan terus mekakukan pembelian berulang pada produk/jasa yang kita tawarkan. 8. perhatikan kualitas produk artinya kualitas harus kita jamin, jangan hanya diawal saja berkualitas namun selanjutnya semakin menurun, karena kualitas yang tidak dijaga berdampak sekali terhadap turunnya minat pelanggan terhadap produk jasa kita bahkan sangat mungkin mereka dapat beralih ke perusahaan saingan kita karena merasa kecewa pada kita. 9 . Evaluasi dan Inovasi, maksudnya jangan cepat puas dengan apa yang sudah diraih saat ini, tapi teruslah untuk menghasilkan banyak hal bernilai dan bermanfaat bagi banyak orang, teruslah belajar memperbaiki diri dan perusahaan agar lebih baik lagi, tingkatkan kualitas input dan output yang dihasilkan dan teruslah berinovasi. 10 . fokus memperkuat brand / merk perusahaan, maksudnya perkuat lagi posisi perusahaan kita dimata khalayak ramai, buktikan bahwa brand perusahaan kita layak diperhitungkan dan layak mendapatkan kesetiaan para pelanggan, karena kita mampu terus memberikan yang terbaik untuk semua pelanggan kita.

Sebaiknya kita jangan takut menghadapi resiko, karena apapun yang kita lakukan pasti ada resikonya, karena itu yang terpenting adalah bagaimana kita focus melakukan dan menghasilkan yang terbaik untuk semua orang yang kita sayangi, kita focus memanfaatkan potensi diri sehingga tidak ada waktu yang terbuang sia-sia tanpa ada manfaat yang dihasilkan, dan sesungguhnya segala sesuatu pasti ada sebab dan akibatnya, jika kita berusaha maksimal dan bersungguh-sungguh dalam menjalankan setiap aktivitas, maka hasil yang kita dapatkan Insyaallah adalah yang terbaik.

\section{E. SIMPULAN}

Percaya dirilah yang kuat dalam melakukan setiap aktivitas karena dengan percaya diri tersebut kita mampu menghadapi segala rintangan yang menghadang, kita memiliki semangat membara untuk menyelesaikan sampai tuntas atas apa yang kita mulai, kita bermental baja dalam menghadapi masalah atau cemoohan orang lain, dimana sesungguhnya mereka tidak ada yang benar-benar mengenal siapa jati diri kita, karena sejatinya hanya kita sendiri yang sangat mengenal diri kita, potensi yang ada, kemampuan dan kelebihan yang melekat dan peluang yang tersedia, maka peliharalah dengan rasa percaya diri tersebut, karena percaya diri merupakan hal yang mendorong sikap kita agar selalu optimis menghadapi lika liku kehidupan ini, dan spesial untuk pengusaha, percaya diri sangat dibutuhkan dalam menjalankan usaha, apalagi kalian adalah orang-orang yang berhati sangat baik karena melakukan yang 


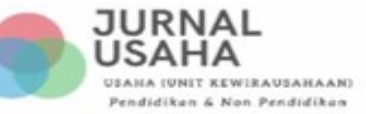

Vol 1, No. 2 (2020), Desember 2020

E-ISSN: 2746-2471, DOI:

terbaik untuk orang lain dengan membantu memberikan lapangan pekerjaan untuk masyarakat yang membutuhkan.

Teruslah berfikir strategis dalam menentukan kebijakan dan langkah terbaik untuk setiap usaha, karena melalui berfikir strategis, Insyaallah kita akan menghasilkan ideide bagus dan cemerlang berserta terbentuknya cara-cara terbaik untuk melakukan kegiatan-kegiatan atas pelaksanaan usaha dengan baik sehingga dapat meraih kesuksesan yang diharapkan. Sesungguhnya, semua dapat dilaksanakan dengan baik jika dimulai dari pemikiran yang baik, positif, optimis dan sensitive terhadap semua kepentingan terkait, maka kebijakan yang lahir adalah yang terbaik untuk setiap orang yang terlibat didalamnya, lalu pelaksanaan akan berjalan lancar dan kondusif, serta hasilnya akan memberikan hasil terbaik untuk semua pihak, tanpa harus ada yang dikalahkan atau dikecewakan baik secara terang-terangan maupun secara sembunyi-sembunyi. Untuk mengatasi persaingan yang ketat dalam dunia bisnis, maka kita memang dituntut agar jeli menghadapinya, dan berawal dari rasa percaya diri dan berfikir strategis itulah kita dapat menghadapi persaingan tersebut dengan persiapan matang, tidak terburu-buru, tidak stress dalam menjalankannya dan dapat melalui setiap rintangan yang ada dengan hati tenang, dengan strategi terbaik tanpa harus menyakiti atau menggeser/mengalahkan pesaing dengan cara yang tidak etis. Karena hal tersbut maka penting bagi setiap pengusaha untuk memiliki rasa percaya diri yang kuat dan kemampuan berfikir strategis yang terbaik agar dapat memenangkan persaingan bisnis yang semakin ketat. 
Vol 1, No. 2 (2020), Desember 2020

E-ISSN: 2746-2471, DOI:

\section{DAFTAR PUSTAKA}

\section{Al-Qur'anul karim}

Apriyanti, M. E. 2020. "Pentingnya Manajemen Diri Dalam Berwirausaha." Usaha (unit kewirausahaan) Unindra 1(1).

Argene. R, 2003, "Strategi Menjadi Wiraswasta Handal”, CV. Restu agung, Jakarta. Diandra D, 2016, "Strategi Membangun Bisnis Mandiri - Gerakan 1001 Entrepreneur Muda Indonesia”, PT. Gramedia Pustaka Utama, Kompas Gramedia, Jakarta.

Feriyanto A dan Triana E.S, 2015, "Komunikasi Bisnis, Strategi Komunikasi Dalam Mengelola Bisnis, Mediatera”, PT. Pustaka Baru, Yogyakarta.

Fathya F. 2014. "9 TIPS AMPUH MENINGKATKAN PERCAYA DIRI DALAM BISNIS.” blog.sribu.com.

Hosting, id cloud. 2019. "Tips and Trick Strategi Pemasaran Yang Efektif Dan Efisien Dalam Bisnis Online."

Iman N, 2017, "Mapan, Perjalanan Menuju Kebahagiaan dan Kebebasan Finansial”, PT. Elex Media Komputindo, Kompas Gramedia, Jakarta.

Izna Faruq. 2020. "9 LANGKAH UTAMA UNTUK MEMENANGKAN PERSAINGAN BISNIS DAN USAHA.” centrausaha.com.

Mamlu'ah, Aya. 2019. “KONSEP PERCAYA DIRI DALAM ALQURAN SURAT AL IMRAN 139.” Al- AUFA Jurnal pendidikan dan kajian keislaman 1(1).

Muhyi H.A, Muttaqin Z., Nirmalasari H., (2016), “HR Plan dan Strategy”, Raih Asa Sukses, RAS, Jakarta.

Rachman. E, 2016, “Sukses Jadi Nomor 1", PT. Gramedia Pustaka Utama, Kompas Gramedia, Jakarta.

Rachman. E, 2016, "Sukses Mawas Diri Untuk Memenangkan Kompetisi", PT. Gramedia Pustaka Utama, Kompas Gramedia, Jakarta.

Rifati, mas ian, Fajriani N, Maghfiroh V, and Arumsari A. 2018. "Kepercayaan Diri Dalam Perspektif Islam.”.

Soegoto ES, 2014, “Entrepreneurship : Menjadi Pebisnis Ulung”, PT. Elex Media Komputindo, Kompas Gramedia, Jakarta.

Sugiyono, 2007, "Metode Penelitian Pendidikan, Pendekatan Kuantitatif, kualitatif dan R\&D”, Bandung, Alphabeta.

Wibowo 2017, "Manajemen Kinerja", PT. Raja Grafindo Persada, Rajawali Pers, Depok.

Zahiraccounting. 2020. "PERSAINGAN BISNIS, APA PENYEBAB DAN MANFAATNYA.” zahiraccounting.com. 